\title{
P04.31. Determining attitudes and use of complementary and alternative medicine and integrative medicine amongst undergraduates
}

\author{
M Broukhim*', A Reeves, N Huynh, M Liu \\ From International Research Congress on Integrative Medicine and Health 2012 \\ Portland, Oregon, USA. 15-18 May 2012
}

\section{Purpose}

The purpose of this study was to determine the perceptions, attitudes, and use of Complementary and Alternative Medicine (CAM) and Integrative Medicine (IM) in UC Irvine undergraduate students to better understand the current opinion trends and use of CAM/IM amongst students. It was expected that there would be an overall positive outlook, perception, use, and interest in CAM/IM in the current undergraduate population.

\section{Methods}

This is a prospective, cross sectional study using an electronic questionnaire conducted on the undergraduate population at University of California, Irvine from Fall 2010 to Spring 2011. Email invitations were sent to all undergraduate students to participate in this study. All data were collected anonymously and IRB approval was secured from UC Irvine. Descriptive and comparative analysis was done on the twenty-one questions using SPSS 16. Additional support for the study was obtained from the Undergraduate Research Opportunities Program (UROP).

\section{Results}

Out of the 23,000 undergraduates, 2,800 responded to the survey, comprising 12 percent of the campus. Onethird of respondents stated that they had used CAM before. Major drives for using CAM were due to friend/ relative recommendation (18.4\%) followed by efficiency/ effectiveness (13.1\%), and curiosity (12.4\%). Pre-health students' primary preferences for taking education on CAM were classes within their major (72\%), as a requirement for graduation (70\%), as a holistic major or minor (53\%), and outside their major (22\%). It was found that

University of California, Irvine, Irvine, USA only $9 \%$ of pre-health majors taking the survey were not interested in more CAM classes.

\section{Conclusion}

We find that most students are interested in attaining more CAM education if readily available. Additionally, we found an overall interest in CAM, use of CAM modalities, and a desire for further education if provided.

Published: 12 June 2012

doi:10.1186/1472-6882-12-S1-P301

Cite this article as: Broukhim et al:: P04.31. Determining attitudes and use of complementary and alternative medicine and integrative medicine amongst undergraduates. BMC Complementary and Alternative Medicine 2012 12(Suppl 1):P301.
Submit your next manuscript to BioMed Central and take full advantage of:

- Convenient online submission

- Thorough peer review

- No space constraints or color figure charges

- Immediate publication on acceptance

- Inclusion in PubMed, CAS, Scopus and Google Scholar

- Research which is freely available for redistribution
C Biomed Central 